\title{
THE ESLA RIVER BASIN: FROM THE CANTABRIAN MOUNTAIN TO THE DUERO
}

\author{
M. Fernández-Aláez, C. Fernández-Aláez and E. de Luis Calabuig \\ Area de Ecología. Universidad de León. 24071 León. Spain.
}

Key words: River basin, Physico-chemical composition, Mineralization, Nutrients.

\begin{abstract}
A general physico-chemical outline of the Esla basin (northwest Spain) is carried out, based on previous studies of the various sub-basins of which it is composed. With regard to the lithological composition of the drained lands, the River Tera and a large part of the Orbigo basin, with water low in mineral content, differ from the rest of the Esla basin, which generally contains water of a higher mineral content. Bicarbonates and calcium are the predominant ionic forms. However, urban waste increases the amount of sulphates and chlorides as well as raising the level of conductivity considerably. The regulation of the water by the reservoirs, agricultural activities and the presence of villages and towns are the determinating factors of the changes in the concentration of nitrates and phosphates in the basin.
\end{abstract}

\section{INTRODUCTION}

The River Esla is the iongest Cantabrian tributary of the Duero basin and plays a very important role in the fluvial structure in the north-west of the Iberian Peninsula. It is considered to be the most important tributary on the Peninsula. Moreover, one of the most outstanding aspects of its basin is the presence of marked contrasts between the hydrographical networks which form it. These are a result of a diversity of human actions, or in some cases a lack of them, and which affect the fluvial geography.

Broadly speaking, the Esla basin is a centre of intense farming and cattle raising and with some industry, which is not particularly important and is restricted to only a few areas, as well as the coal mines in large areas of the north of the basin which cause pollution that alters the quality of the water on the initial stretches of the rivers, where levels of higher quality would normally be expected. Only three towns have a population of over 10,000 , but none of these possess adequate systems for the purification of sewage. Moreover, more than $50 \%$ of the main rivers in the basin are regulated by reservoirs. Nevertheless, there are rivers in which none of the above-mentioned activities are of particular relevance; their special importance within the basin is due to their abundance of fish.
The possibility of analysing such a heterogeneous river system has led to a series of investigations over the last few years focused on the study of the different rivers making up the basin, from both a biological (FERNANDEZ, 1986; FERNANDEZ et al., 1986a; FERNANDEZ et al., 1987a; FERNANDEZ et al., 1990; FERNANDEZ et al., 1991b; PRESA et al., 1987; PRESA et al., 1988) and physicalchemical (FERNANDEZ et al., 1986b; FERNANDEZ et al., 1987b; FERNANDEZ et al., 1988, FERNANDEZ et al., 1989, FERNANDEZ et al., 1991a) point of view. This paper is based on some of the results obtained.

\section{DESCRIPTION OF THE AREA STUDIED}

\section{The geography of the river basin}

The River Esla is the bigest water collector in the northwest sector of the Duero basin, and carries to it, on the right hand side, the greatest discharge of all its tributaries: 182 $\mathrm{m}^{3} / \mathrm{s}\left(5,113 \mathrm{Hm}^{3}\right)$, which is even greater than its own flow at their confluence point. Its basin, with a surface area of $16,081 \mathrm{~km}^{2}$, becomes fan-shaped between the eastern slopes of the Montes de León and the western slopes of the Cantabrian Mountains, as far as the hills coming south of 


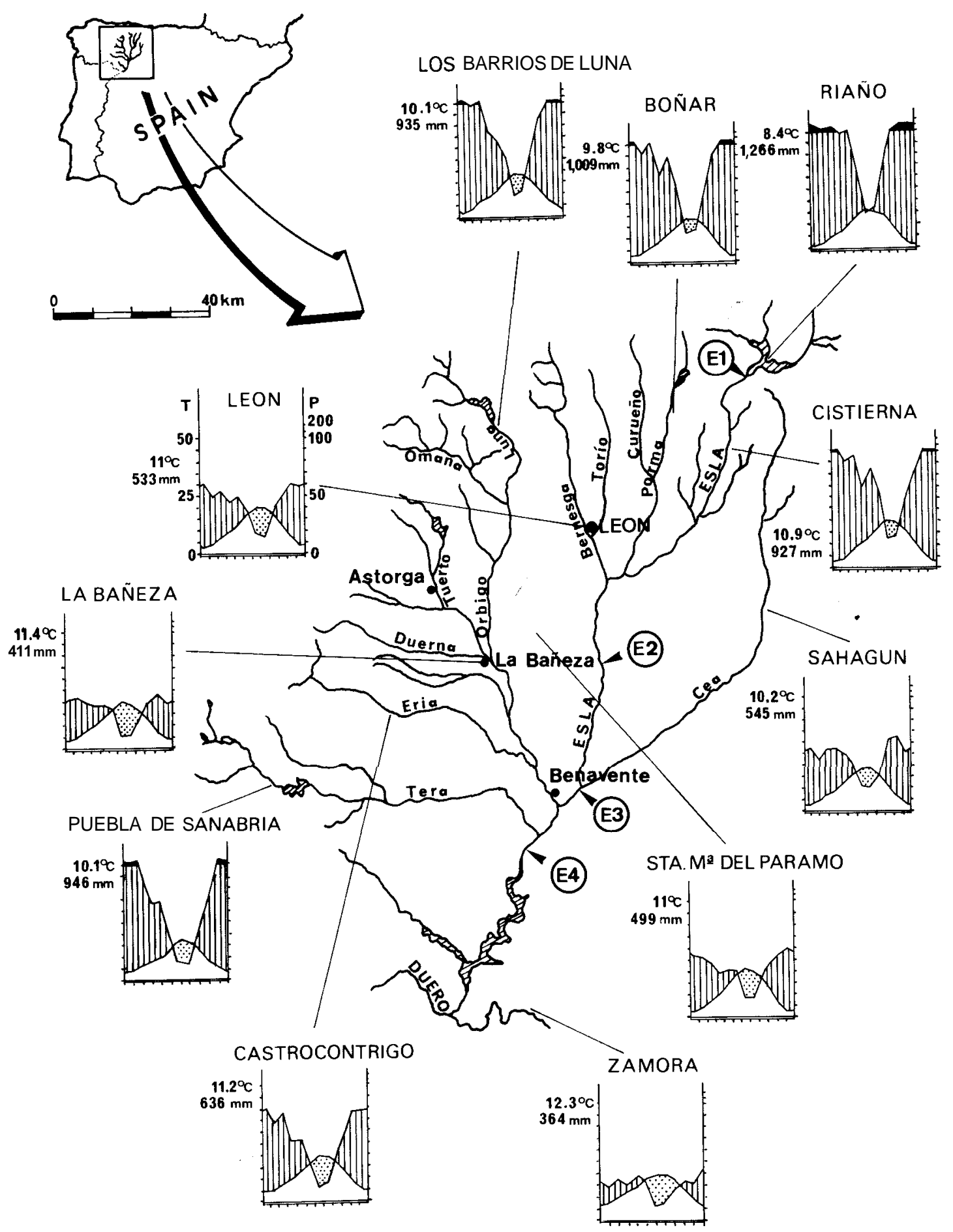

Figure 1. The Esla catchment, together with ombrothermic diagrams from various meteorological stations and the situation of the gauging stations used in figure 4 . 
Peña Prieta, which separate it from the Pisuerga catchment area.

The Esla rises in the Cantabrian Mountain, South of the Picos de Europa, between the natural parks of Mampodre and Riaño. Since January 1988 the upper part of the river has been regulated by the Riaño reservoir $\left(664 \mathrm{Hm}^{3}\right)$. Throughout its course of $275 \mathrm{~km}$ it is fed on its right bank by its most important tributaries, the majority of these being regulated by reservoirs at their sources. It is first joined by the Porma, which drains $1,042 \mathrm{~km}^{2}$, and is regulated by the reservoir of the same name $\left(318 \mathrm{Hm}^{3}\right)$; next by the Bernesga, which flows through the city of León, and has a drainage basin of $1,188 \mathrm{~km}^{2}$. Downstream, having crossed the "Páramo" in León, it is joined by the Orbigo $(4,972$ $\mathrm{km}^{2}$ ), various rivers in the basin of which are regulated by the Barrios de Luna $\left(308 \mathrm{Hm}^{3}\right)$, Selga Ordás $\left(60 \mathrm{Hm}^{3}\right)$ and Villameca $\left(20 \mathrm{Hm}^{3}\right)$ reservoirs. Further down it is joined by the Tera, dammed both at Cernadilla $\left(255 \mathrm{Hm}^{3}\right.$ ) and Valparaiso $\left(260 \mathrm{Hm}^{3}\right)$, which increases the volume of the water with an average annual discharge of $300 \mathrm{Hm}^{3}$. Finally, it is joined by the Aliste, the waters of which run into the Ricobayo reservoir. The Cea, which crosses the province of Leon from north to south is the most important tributary of the Esla on its left bank. Before flowing into the Duero, the waters of the Esla are held back by the Ricobayo reservoir $\left(1,200 \mathrm{Hm}^{3}\right.$ ) (fig. 1).

Figure 2 shows the longitudinal profiles of the Esla and its main tributaries.

\section{Geological characteristics}

In relation to the geological structure, the river basin can be divided into three basic parts (fig. 3):

1. The most northern band, made up of the southern slopes of the Cantabrian Mountain including the upper half of the sub-basins of the Bernesga and the Porma and the initial stretches of the Esla, the Cea and the Luna, is of great diversity and lithological complexity. It is made up of mainly Paleozoic materials, predominantly sandstone, quartzite, shale and coal, together with small bands of limestone.

2. The southwestern edge, with the River Aliste, the upper half of the Tera and the sources of the tributaries of the Orbigo, consists of shale and quartzite of Paleozoic origin.

3. The central-eastern section of the catchment area consists of Miocene sandy clay mixed with Plio-Quaternary detrital deposits ("raña"), together with Quaternary alluvial deposits along the river banks.

\section{Climate and Hydrology}

In accordance with ALLUÉ ANDRADE's classification of phyloclimatic subregions (1966) the climate in the Esla

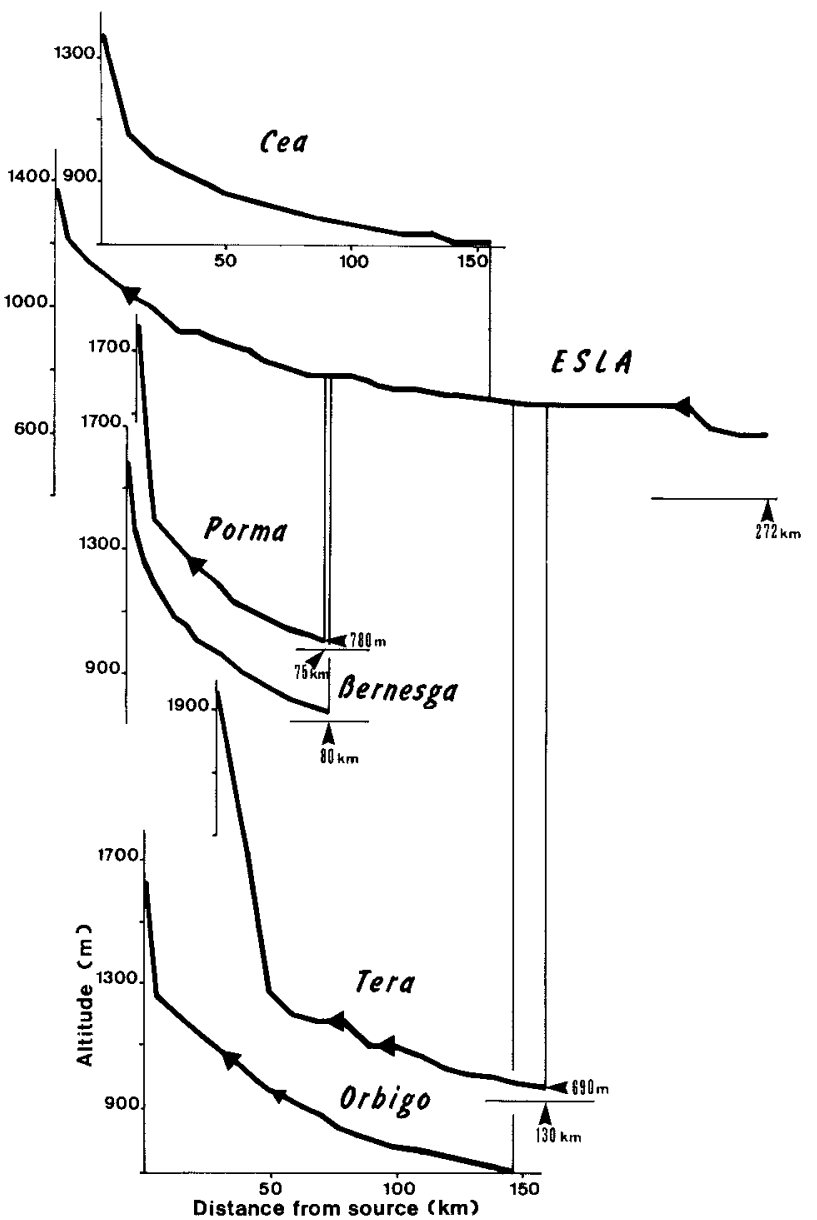

Figure 2. Lomentudinal prostles of lhe mos important rivers in the Esla basin, showing the location of the reservoirs.

basin varies from that designated to high mountain, which together with Central-European predominates in the northern section of the basin, to the genuine Mediterranean climate, moderately warm, dry, with cool winters, which characterizes the southeastern part of the basin. While at the source of the Esla the average annual rainfall is about 1,300 $\mathrm{mm}$, with an average annual temperature of $8{ }^{\circ} \mathrm{C}$, in the lower reaches of the basin, the average values are of about $500 \mathrm{~mm}$ and $11^{\circ} \mathrm{C}$ respectively (fig. 1 ).

The analysis of the fluctuations in the flow over the years allows for a definition of the type of hydrological system presented by a river. To this aim, the records of the discharge over nine hydrological years (October 

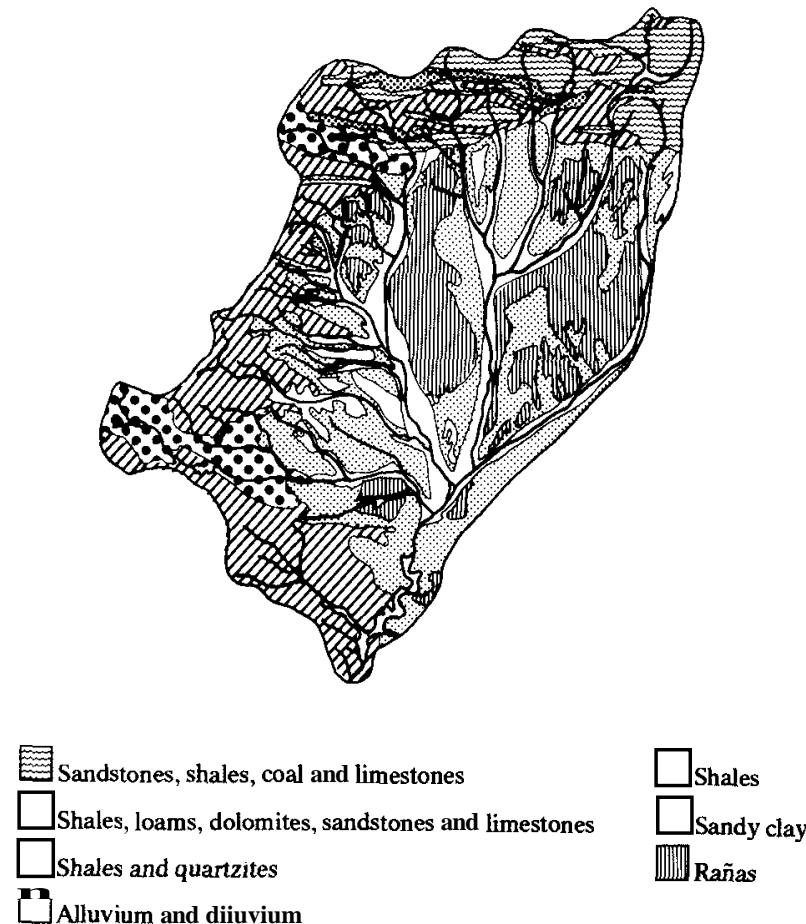

Figure 3. Map of the limolegical formalloms of the tesla basin

1980-September 1989) from four gauging stations situated on the Esla were used. As can be seen from the figure 4 , the annual variation in the discharge is basically similar throughout the whole river, although a high increase in the flow is produced as the most important tributaries join it.

The maximum flows correspond to spring, in particular to April(200.91 $\mathrm{m}^{3} / \mathrm{s}$ in E4) as a result of thawing at the headwaters in the mountains. However, since at the end of the autumn the rainfall is generally heavy there is, of course, an increase in the discharge measured at the gauging stations in the lower stretches, beyond the confluences of the Cea, the Orbigo and the Tera. During the summer period, in particular in August, minimum flows are registered in the lower half of the river (E2: $10.54 \mathrm{~m}^{3} / \mathrm{s}, \mathrm{E} 3: 19.75 \mathrm{~m}^{3} / \mathrm{s}, \mathrm{E} 4: 30.12 \mathrm{~m}^{3} / \mathrm{s}$ ) as opposed to the area around the source, where retention in the form of snow leads to a minimum flow in November $\left(5.23 \mathrm{~m}^{3} / \mathrm{s}\right)$.

The marked variations in the flow throughout the year reflect the irregularity of the Mediterranean climate, and determine the hydrological system of the Esla as pluvialnival. During the winter the level of the water is low since it is accumulated in the form of ice and snow at the source. An important increase in the volume is produced in spring as a result of thawing.
The recent regulation of the Esla has led to a distortion in the system of the river, since it has given rise to a marked increase in the volume of the water carried by the river during the summer.

\section{Population and land use}

Large sections of the river basin which are situated on its marginal areas show a density of not over 15 inhabitants per $\mathrm{km}^{2}$. In certain areas, generally those situated around the River Orbigo, there are 125 inhabitants per $\mathrm{km}^{2}$ and even up to 500 in towns such as Benavente, Astorga and La Bañeza. However, the greatest density corresponds to the city of Leon with 3,409 inhabitants per $\mathrm{km}^{2}$. This is the most populated city in the Esla basin, and is, therefore, the most important centre of pollution, since the Bernesga and the Torío receive its non-purified urban and industrial waste waters.

Land use in the catchment area allows for a clear differentiation of the mountainous areas which are situated in the north and west and are largely covered with wide areas of scrub land and grazing land. There are irrigated meadows around the river banks and there are wooded areas of coniferous and deciduous trees, particularly around the source of the Esla. The rest of the basin is generally given over to intensive agriculture and there are orchards and irrigated farmland along the Orbigo and the Esla and on the "Páramo" in León.

The industrial development of the river basin is, however, of relatively little significance. It is mainly found in the city of León, where the most important sectors are the pharmaceutical and the sugar factories. The latter is of impor-

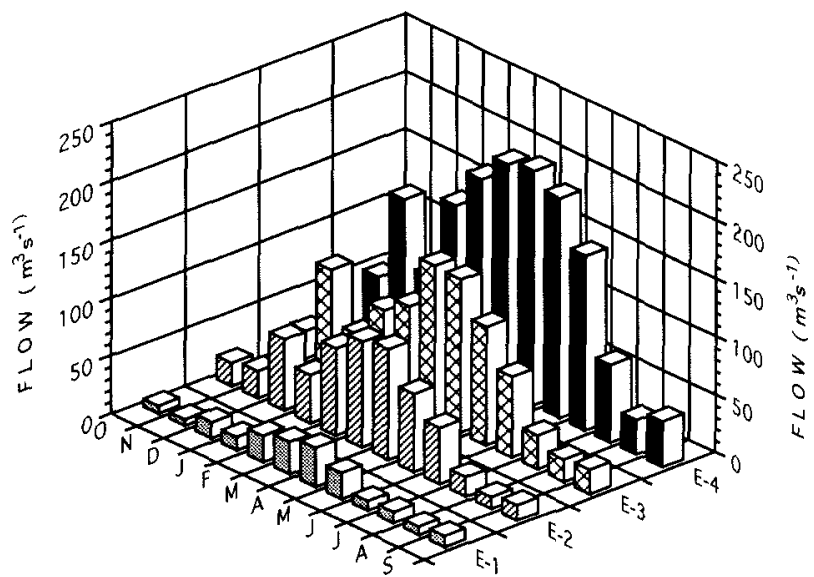

Figure 4. Annual variation in the alverage discharge at the four selected gauging stations on the River Esla. 
tance throughout the river basin, and its waste affects the Bernesga, the Orbigo and the Esla. Also of importance is the energy sector, based on the production of coal and hydroelectricity. The most important coal deposits are in the northern section, in the Ciñera-Matallana mining valley, situated between the Bernesga and the Curueño, and the Sabero valley, between the Porma and the Esla.

\section{METHODOLOGY}

In order to characterize the Esla basin from a physical and chemical point of view, 126 sample stations were set up along the different rivers. The collection of samples of water took place seasonally during the period from 1985 to 1990. The following physical and chemical parameters were determined: temperature, total solids in suspension, $\mathrm{pH}$, conductivity, dissolved oxygen, alkalinity, nitrates, nitrites, ammonium, phosphates, sulphates, chloride, silicates, calcium. magnesium, sodium and potassium. The analytical methods used are outlined in FERNANDEZ et al. (1987b).

\section{RESULTS AND DISCUSSION}

\section{Mineral composition of the river basin}

The synthetic study of the physical and chemical characteristics of the main sub-basins that form the Esla basin through the principal component analysis always resulted in a basic factorial plane in which the sample points fundamentally followed an order in relation to the mineralization of the water. This characteristic of the waters has been found to contain either a combination of the first two components, or else with the two apart. In the second case, alkaline-type mineralization, more closely linked to the lithological composition of the river basin is related to component 1 , while component II represents the mineralization produced by human activities.

The global ionic content of water is known to be directly related to conductivity (HAUBERT, 1975), and moreover its dependence both on the lithological composition of the drained lands (OTTO, 1983) and on the dissolved waste of human origin (MEYBECK, 1979) is evident. In order to offer a simple concept of the physical and chemical composition of the rivers in the Esla basin, the measurement of the electric conductivity of the water as a representative characteristic of its mineralization has been chosen for this reason.
After determining a series of intervals, figures 5 and 6 show the values of conductivity registered in the sampling stations of the basin. It has been decided to refer to the results of the spring and summer periods, since these are the two extreme periods of volume with relation to the hydrological system in the river basin. The modifications produced by the regulating effect of the reservoirs should, however, be taken into account.

Under high flow conditions, the values registered varied between $24 \mu \mathrm{S} / \mathrm{cm}$ in the Tera and $412 \mathrm{uS} / \mathrm{cm}$ near the mouth of the Bernesga. In summer the range of variations increased, although the extreme values were still found in the same stretches of the river basin: the headwaters of the Tera, with $19 \mathrm{uS} / \mathrm{cm}$ and the final stretch of the Bernesga with a conductivity slightly above $1,000 \mathrm{uS} / \mathrm{cm}$. The least mineralised waters generally corresponded to the tributaries of the Orbigo, to the Tera and in particular to certain sample stations at the head of the river basin. However, in contrast to the low conductivity in the greater part of the tributaries of the Orbigo, the upper courses of this sub-basin show a significant increase in ionic content, up to over 200 $\mu \mathrm{S} / \mathrm{cm}$. The particular lithological composition of the drai-

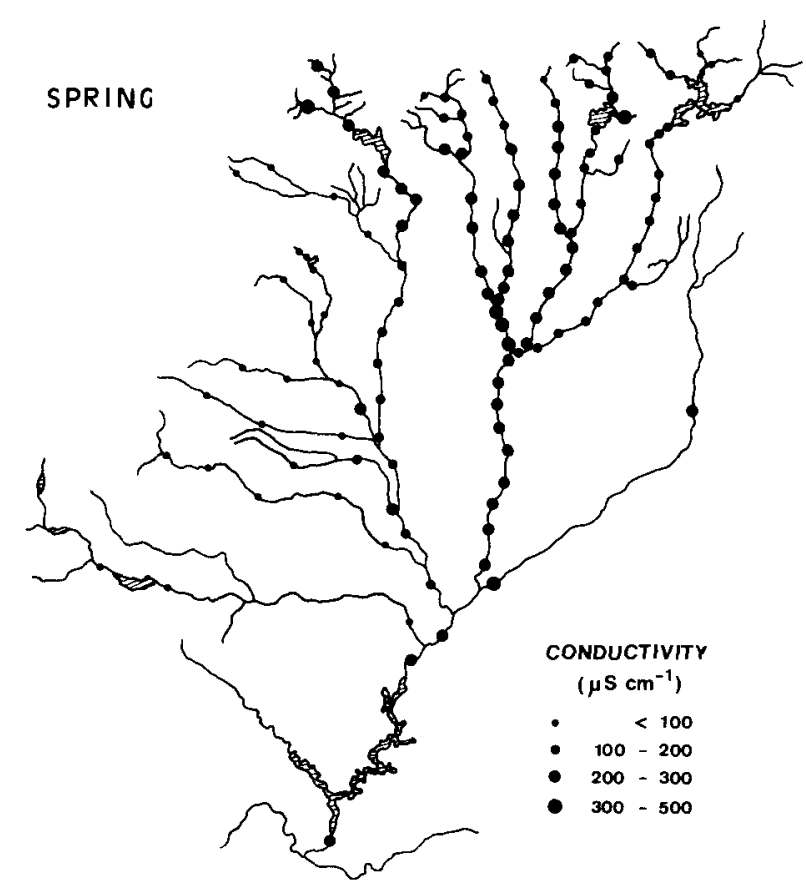

Figure 5. Location of the sampling statıons. Distribution of the values of conductivity measured in the catchment during the spring. 


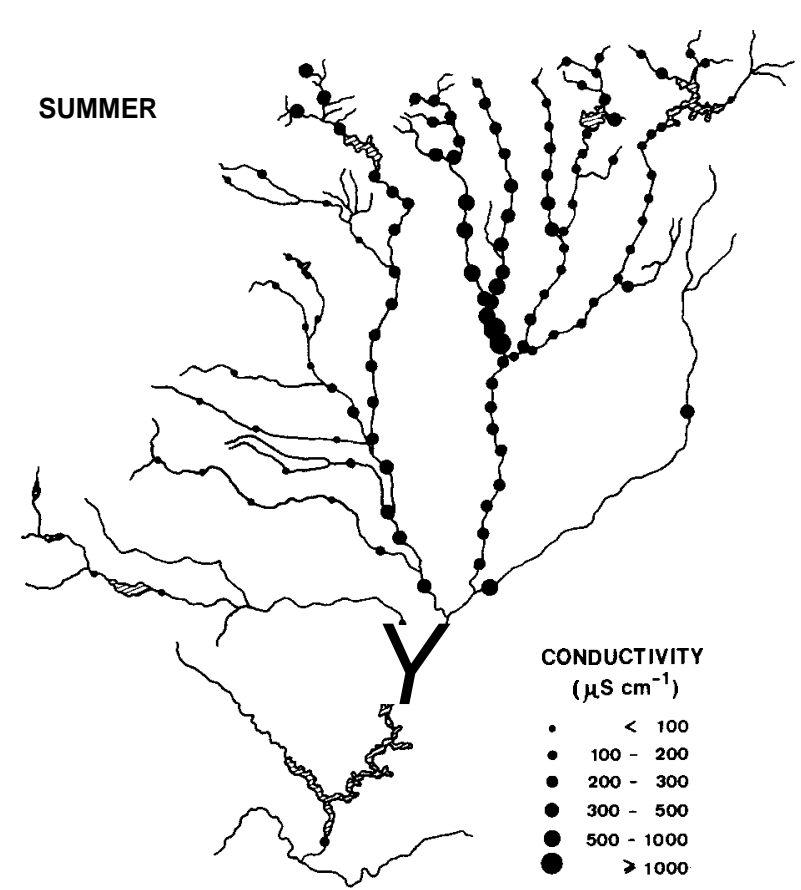

Figure 6. Distribution of the values of conducunas measured in the catchment during the summer.

ned lands is the cause of these differences, although siliceous materials predominate there are also some small limestone layers.

During the spring, in the middle and lower stretches of the Orbigo the conductivity was reduced with respect to the source up to $100-200 \mu \mathrm{S} / \mathrm{cm}$ due to the effect of dilution brought about by the incorporation of siliceous tributaries. In summer, however, and after a slight decrease just after the dam, levels of mineralization closer to those at the source were registered right along the Orbigo; even in the lower river they were over $300 \mu \mathrm{S} / \mathrm{cm}$. The reason for this is the contribution of ions, particularly chlorides and sodium, which clearly influence the global mineralization of the water during the period of minimum discharge, and which derive from the important influence of human activities on the riverbanks. It should be noted that in spite of the effect of the reservoir, the flow of the Orbigo in the lower stretch is lower in summer $\left(11.09 \mathrm{~m}^{3} / \mathrm{s}\right)$ than in spring $\left(51.15 \mathrm{~m}^{3} / \mathrm{s}\right)$ due to the reduction in the water volume supplied by the tributaries, the final sections of which also appear to be affected by pollution.

The rest of the Esla basin as a whole contains waters of higher mineral content, particularly the Bernesga sub-basin. Both in the Bernesga and the Torío there is a general tendency in the course of the river towards a gradual increase in conductivity from the headwaters to the mouth, a result of the progressive accumulation of salts proceeding from the washing of the land and the waste of human origin (MARGALEF, 1983). In both rivers there is a sharp drop in flow in summer, as a result of which the mineralization increases considerably and the effects of pollution are intensified. The conductivity at the upper Torío is situated at about $200 \mathrm{uS} / \mathrm{cm}$, whilst at its mouth it reaches $500 \mathrm{uS} / \mathrm{cm}$. In the middle stretch of the Bernesga the impact of the coal mines together with the development of large centres of population is important, provoking high contributions of sulphates, chlorides and sodium. But the effect of contamination is even greater after the confluence with the Torío, when the Bernesga receives the waste from the city of León and its conductivity rises to $1,136 \mathrm{uS} / \mathrm{cm}$.

The Curueño is similar to the Torío. The ionic content increases as the drained surface area does, even more so in the summer with the decrease in volume. In contrast, and due to the reservoir, the Porma shows little variation in conductivity from its source to its mouth during the summer. Moreover, it does not generally reach over $200 \mathrm{uS} / \mathrm{cm}$.

Although in spring no important variation was registered along the river, these levels were surpassed after it was joined by the Curueño.

The mineralization also varied little along the Esla. The conductivity is below $200 \mathrm{uS} / \mathrm{cm}$ until the entry of the rivers of the Bernesga sub-basin; it then increases only slightly and does not rise above $300 \mathrm{uS} / \mathrm{cm}$. The uniformity of the mineralization values is explained on one hand by the presence of the Riaño reservoir, at the upper river, and on the other hand by its significant reduction in the water flow in summer, even though the ionic content remains the same in the same season. When the Esla joins the Duero the conductivity is below $300 \mathrm{uS} / \mathrm{cm}$ and even in summer it carries water that is relatively low in minerals to the Duero.

Typification of the river basin based on the ionic composition

Considering the samples of the basins of the Porma, the Bernesga, the Orbigo and the Esla with its small tributaries at the source independently, the proportion of ions has been calculated and then represented in triangular diagrams.(figs 7 and 8) In this way a typification of the water in all the samples is obtained, with a separate representation of the percentage of the majority anions (bicarbonates + carbonates, chlorides and sulphates) and cations (calcium, magne- 
sium and sodium + potassium) for the two selected sample periods: summer and spring.

As can be observed in figure 7, the geo-chemical group into which all the samples from the River Esla and all the small tributaries at the source are included is the bicarbonate-calcic one.

As regards the Porma basin, the dominant proportion of mineralization is also made up of bicarbonates and calcium. The samples from the Curueño and the small tributaries of the Porma contain more bicarbonates and are slightly different from those from the Porma in the spring sampling. Although bicarbonates consistently represent over $50 \%$ of the total anions, the proportion of sulphates increases at the source of the Porma because of the influence of the lithological characteristics. Calcium continues to be the main cation, there is a high proportion of magnesium, and a minimum presence of sodium and potassium in the ionic content (fig. 7).

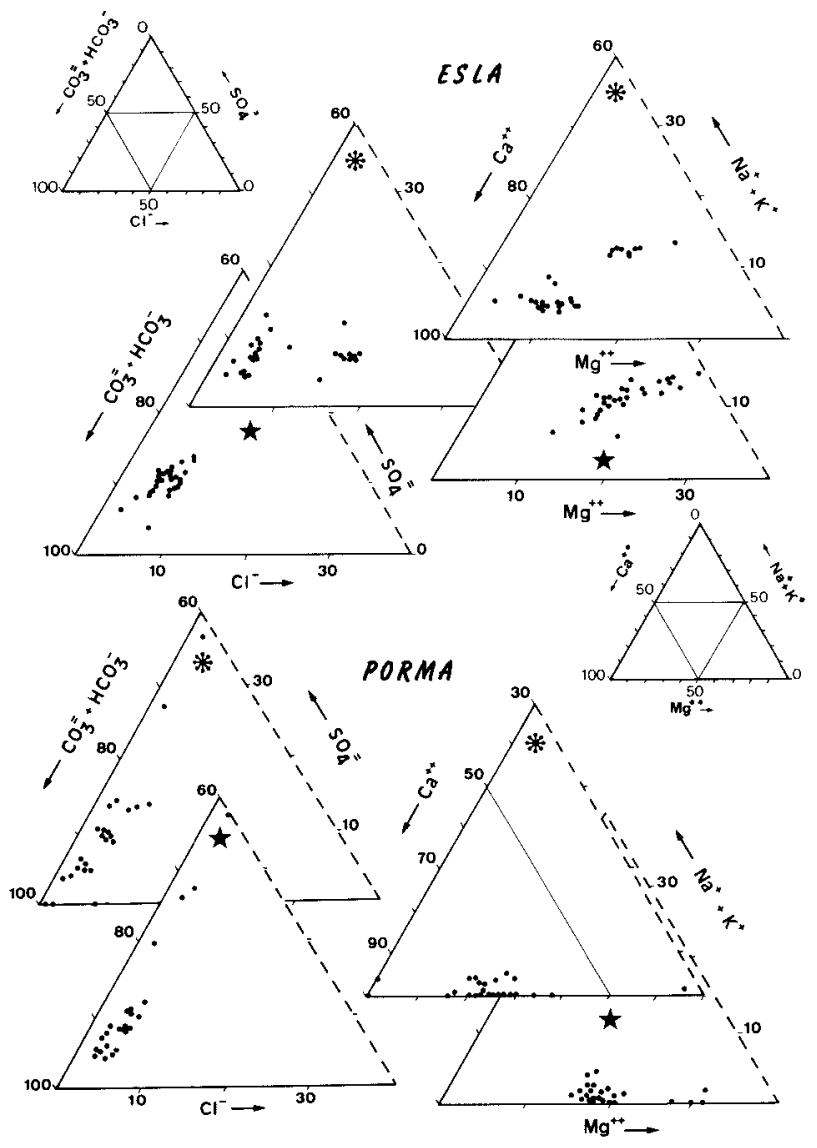

Figure 7. Triangular diagrams of the majorty forms. Ine data reter to the samples taken in spring and summer for the Esla river and the Porma catchment.
As shown in figure 8, the Orbigo basin is more heterogeneous as regards its proportions of ions. There is still a clear predominance of bicarbonates in the relation of the anions; however certain samples in tributaries, such as the Tuerto and the Jamuz affected by the pollution from small villages, are more widely dispersed, due, basically, to the increase in the percentage of chlorides. In the triangular diagram of the cations, calcium is also dominant, but in a group of samples belonging to the Tuerto, the Jamuz, the Brañuelas and the Eria the other cations, in particular magnesium, are of greater importance.

Among the ions in the Bernesga basin there is a high predominance of bicarbonate and calcium. This is even more marked in the Torío, and it is maintained throughout its course. In the Bernesga, however, there are some exceptions, due to the effects of pollution. On the one hand, the coal mines at the upper parts of the basin increase the amount of sulphates, and on the other. urban waste increases
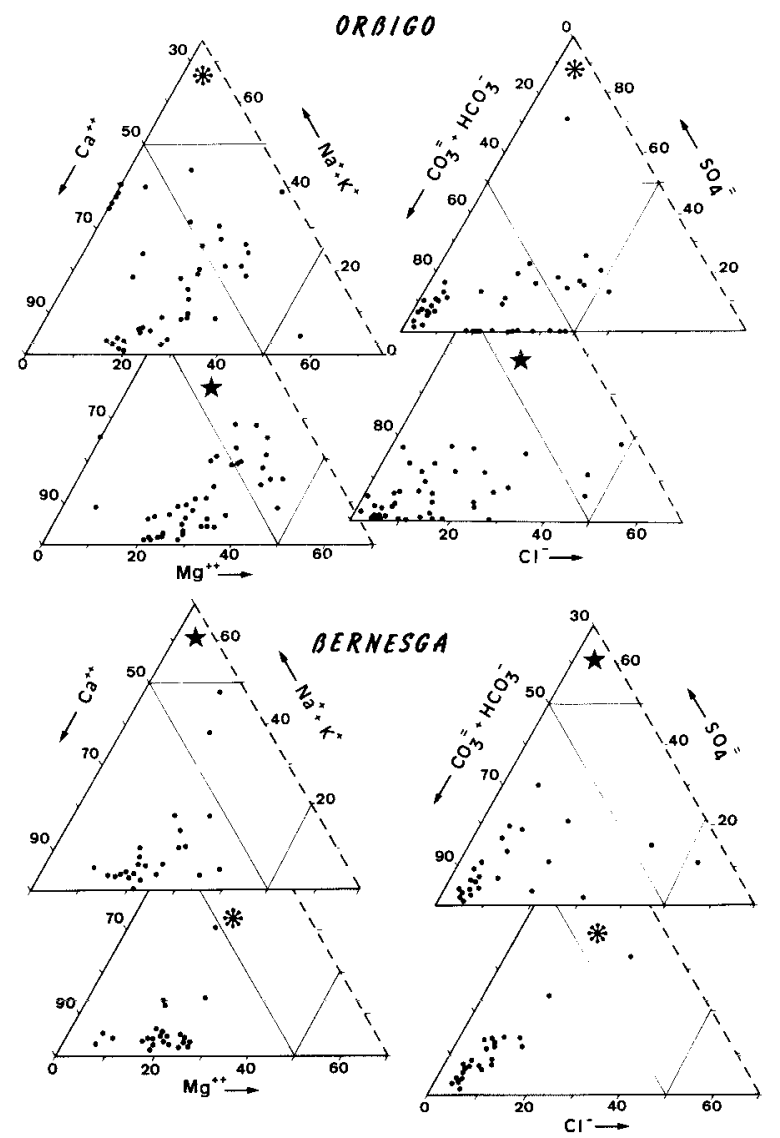

Figure 8. Triangular diagrams of the majorlty roms. I he data refer to the samples taken in spring and summer for the Orbigo and the Bernesga catchment. 
the proportion of chlorides and sodium, especially in the summer (fig. 8 ).

\section{Phosphates and nitrates}

Figures 9 and 10 show the variation in space and time in the $\mathrm{N}$-nitrate and $\mathrm{P}$-phosphate content during spring and summer in the rivers in the basin which have been the object of greater study.

With regard to soluble reactive phosphate, the relative singularity of each of these rivers determines the existence of differences in the evolution followed by the said nutrient. In the first place, a differentiation can be made between the rivers which are regulated (the Porma. the Orbigo, the Esla) and those which are not (the Curueño, the Torío, the Bernesga). In the latter, the reduction in volume during the dry season leads to a general increase in the concentration of orthophosphate particularly in the stretches downstream from the larger towns. The content of this nutrient is particularly high in the final stretch of
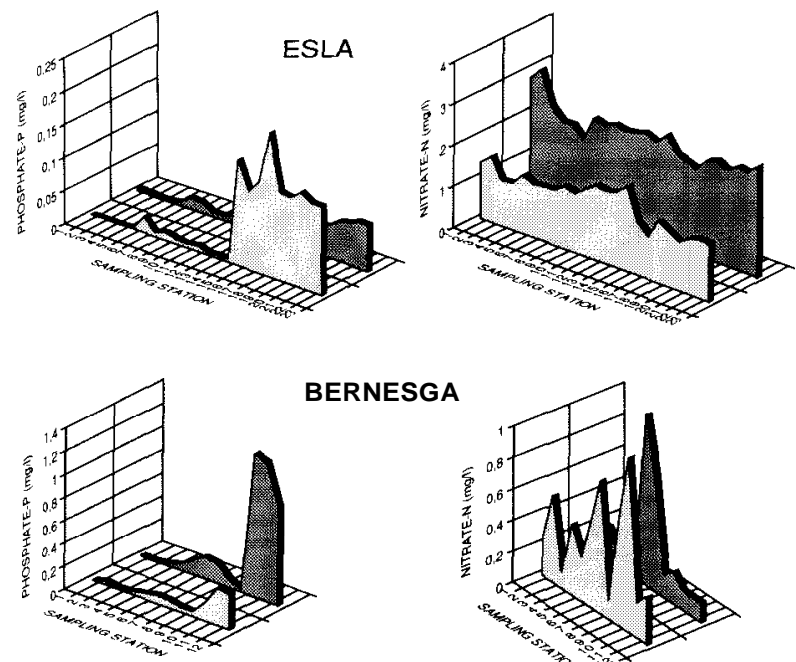

BERNESGA
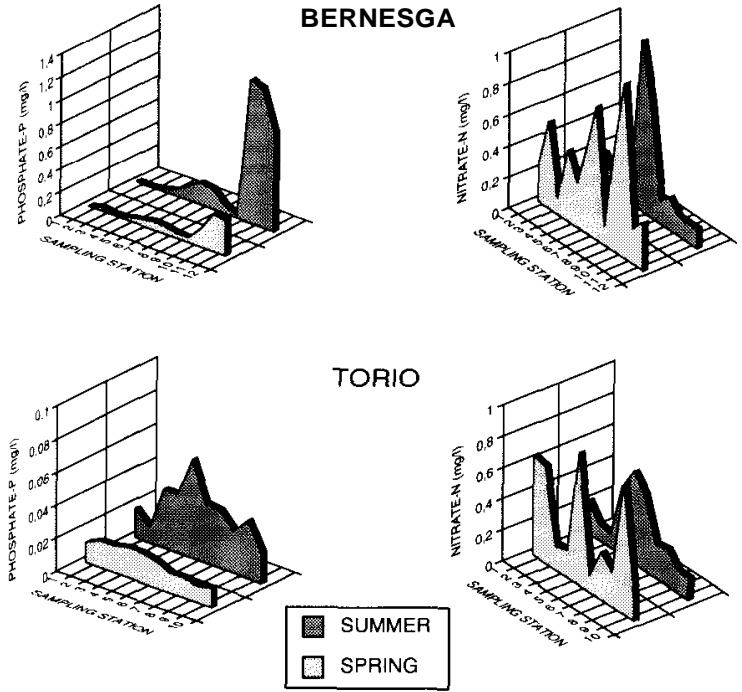

Figure 0. Variation prolles of the P-Phosplate and $N$-Nitrate along the Esla, the Bernesga and the Torío. the Bernesga; downstream from the city of León, with a maximum of $1.24 \mathrm{mg} / \mathrm{l}$ (fig. 9).

In the rivers which are regulated, the use of water retained by the dam during the summer leads to a process of dilution, and, therefore, to reduction in the concentration of orthophosphate compared with the spring. The greater increases in this nutrient correspond to areas of greater density of population in the catchment area, together with an increase in agricultural activity and the washing of the land, which is particularly high in spring in the areas around the source.

The high pollution in the final stretch of the Bernesga clearly affects the phosphate levels found in the Esla downstream from the confluence of the two rivers. However, the decline in industrial activity during the summer in which the Esla was sampled has led to a considerable decrease in the concentration of this nutrient in relation to the values obtained in spring (fig. 9).

Nitrate is the most abundant inorganic form of nitrogen in the Esla basin, with a maximum concentration in the two
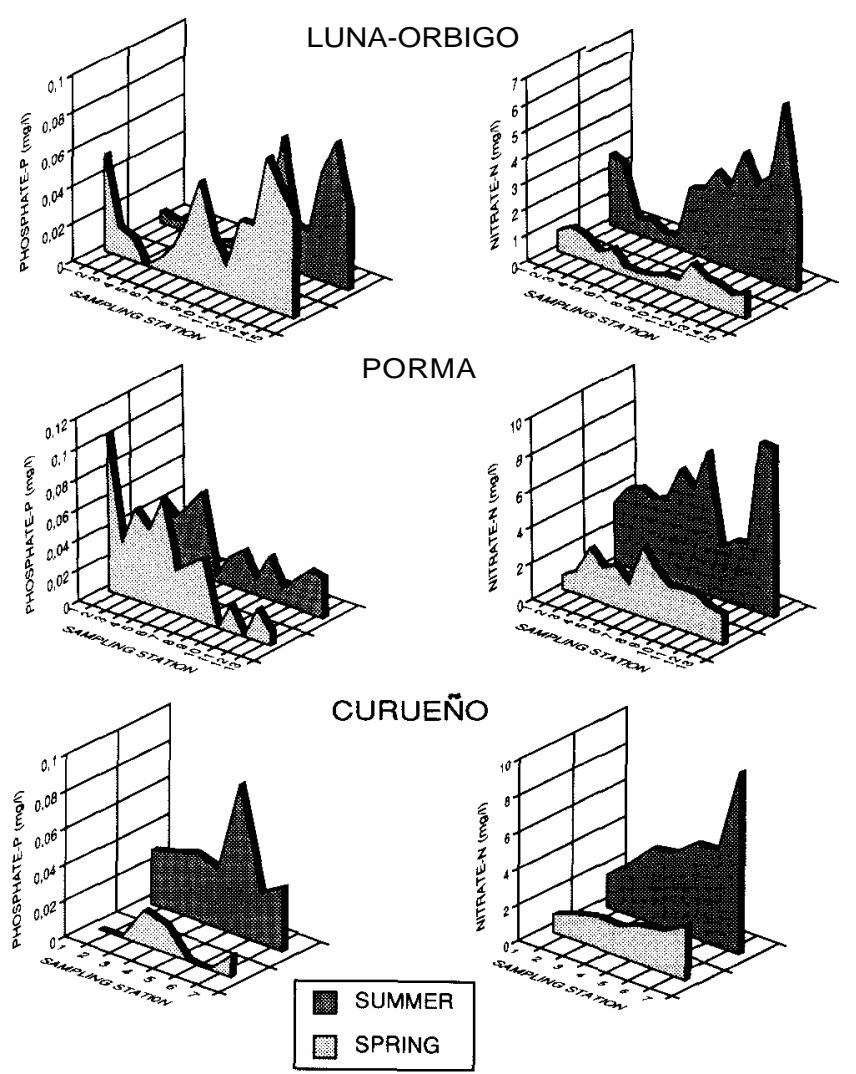

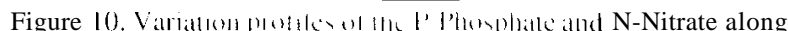
the Luna-Orbigo, thr Porma and the Curueño. 
seasons under consideration of $9.99 \mathrm{mg} / \mathrm{l}$, registered in the Curueño, and a ininimum content of $0.091 \mathrm{mg} / \mathrm{l}$, measured in the Torío.

The regulation of the Esla involves very little seasonal variation and the nitrate content is practically homogeneous throughout its course. However, the other regulated rivers do not offer the same findings, as the concentration of this nutrient in the Orbigo and the Porma undergoes an increase in the summer and there are marked fluctuations. These are occasioned by contributions particularly of agricultural origin and by an increase in the importance of ammonia in the sections affected by urban waste, as well as by the retention generated, in some cases, by the reservoirs.

In the Bernesga and the Torío there is no clear separation between the nitrate contents measured in spring and summer; nor do they reach the levels found in the other rivers in the basin. The reduction in volume in the summer cuts down the quantity of nitrate in the lower reach of both rivers, in particular that of the Bernesga, where the conditions of almost total anoxia lead to the process of denitrification, increasing the ammonia content.

The Curueño is the only river in which a clear correlation between the nitrate content and the drained surface area can be observed.(fig. 10). This characteristic is more evident during the very dry season, which is not accompanied by a drastic decrease in oxygen content, and produces a higher concentration of this nutrient in the final stretch.

\section{ACKNOWLEDGEMENTS}

We should like to thank the Joint University of LeónLeón Provincial Council Commission for financing the research projects that have made this study possible.

\section{REFERENCES}

ALLUE, A.J.L. 1966. Subregiones fitoclimáticas de España. IFIE. Ed. Ministerio de Agricultura, Madrid.

FERNANDEZ ALAEZ, C. 1986. Gradiente estructural de la vegetación macrófita acuática y ribereña y valoración de factores ecológicos en el río Bernesga, León. Tesis Doctoral. Universidad de León, 344 pp

FERNANDEZ, C., E. LUIS \& M. FERNANDEZ 1986a. Gradiente longitudinal de distribución de la vegetación ribereña del río Bernesga (León) en su tramo de montaña. Anales de Biología, 8: 35-44.
FERNANDEZ, C., E. LUIS \& M. FERNANDEZ. 1986b. Análisis de correlaciones canónicas aplicado al estudio de la relación entre la composición físico-química del agua y suelo aluvial en el río Bernesga (León). Limnetića, 2: 85-93.

FERNANDEZ, C., E. LUIS \& M. FERNANDEZ 1987a. Distribución de la vegetación macrófita en la cuenca del río Orbigo (León). Actas del IV Congreso Español de Limnología: 191-202.

FERNANDEZ, M., Y. IBAÑEZ y C. FERNANDEZ 1987b. Estudio físico-químico de los ríos de la cuenca del Bernesga (León).Actas del IV Congreso Español de Limnologia: 179-190.

FERNANDEZ C., M. FERNANDEZ \& E. LUIS 1988. Variations in time and space of some physical and chemical variables in the Bernesga river (León, Spain). Annls. Limnol., 24(3): 285-291.

FERNANDEZ, C., E. LUIS \& M. FERNANDEZ. 1989. Caracterización físico-química de la cuenca del río Orbigo (León, España). Actas del Coloquio Luso-Espanhol sobre Ecología das Bacias Hidrograficas e Recursos Zoologicos, 103-111.

FERNANDEZ, C., M. FERNANDEZ, \& E. LUIS. 1990. Estudio comparado de la vegetación macrófita acuática y ribereña de las cuencas altas de los ríos Sil, Porma y Orbigo (León). Monografías del Instituto Pirenaico de Ecología, 5: 387-396.

FERNANDEZ, C., E. LUIS \& M. FERNANDEZ. (1991a). Caracterización físico-química de los ríos de la cuenca del Porma (León). Scientia Gerundensis, 16

FERNANDEZ, M., C. FERNANDEZ \& A. DEL RIO. (1991b) Estudio comparativo de los ríos de la cuenca del Orbigo (León) en base a las variaciones en la estructura y composición de las comunidades de macrófitos. Scientia Gerundensis, 16.

HAUBERT, M. 1975. Bilan hydrochimique d'un basin versant de moyenne montagne: la Dranse de Bellevaux (ou Brevon), Haute Savoie. Thèse 3 e cycle. Université Pierre et Marie-Curie, París.

MARGALEF, R. 1983. Limnología. Omega, Barcelona, $1.010 \mathrm{pp}$.

MEYBECK, M. 1979. Concentrations des eaux fluviales en éléments majeur et apports en solution aux oceans. Rev. Geol. Dyn. Geog. Phys., 21(3): 215-246.

OTTO, A. 1983. Natural site-specific basic values of the chemism of (surface) waters (Base load) in different regions of the Federal Republic of Germany. Proceedings of a MBA Project 5 Workshop. Budapest. Octubre 1983, $14 \mathrm{PP}$. 
PRESA, Y., E. LUIS \& J. DE SOTO. 1987. Análisis de las comunidades de macroinvertebrados de la cuenca del río Orbigo. León. Actas del IV Congreso Español de Limnología. Sevilla, 203-213.

PRESA, Y., E. LUIS, J. DE SOTO \& M. POSTIGO.
1988. Análisis comparativo de los macroinvertebrados en dos subcuencas de diferente sustrato litológico. Actas do Coloquio Luso-Espanhol sobre ecología das bacias hidrográficas e recursos zoológicos. Porto, 327-334. 